Dialectologia 15 (2015), 159-179.

ISSN: 2013-2247

Received 4 June 2014.

Accepted 11 September 2014.

\title{
THE REALLOCATION OF [j] IN CYPRIOT GREEK
}

\author{
Panayiotis A. PAPPAS \\ Simon Fraser University \\ panayiotis_pappas@sfu.ca
}

\begin{abstract}
This article examines the variation between lateral palatal $([\Lambda])$ and fricative palatal $([j])$ instantiations of the variable (liV) in Cypriot Greek. Through the analysis of two datasets, one based on sociolinguistic interviews, and one based on elicitation tasks, it is shown that the fricative variant, which used to be associated mainly with the city of Ammochostos (Famagusta), is now present in all three major urban centres of the island, and that young men are leading the change. The circumstances that led to this development are examined from the perspective of the socio-psychological model proposed by Britain (1997), and it is argued that this is a case of socio-stylistic reallocation (Trudgill 1986). Viewed within the context of sociolinguistic tension that has existed between Cypriot Greek and the standard varieties for more than a century, the emergence and spread of a native variant is seen as another sign that the status of Cypriot Greek vernacular is increasing within the community.
\end{abstract}

\section{Keywords}

Greek, dialects, Cypriot, reallocation, laterals

\section{LA REASIGNACIÓN DE [j] EN GRECOCHIPRIOTA}

\section{Resumen}

Este artículo estudia la variación entre la palatal lateral $([\Lambda])$ y la palatal fricativa ([j]) las soluciones de la variable (LiV) en grecochipriota. A través del análisis de dos conjuntos de datos, uno basado en entrevistas sociolingüísticas y otro basado en tareas de elicitación, se muestra que la variante fricativa, que solía estar asociada principalmente con la ciudad de Ammochostos (Famagusta), está ahora presente en los tres principales centros urbanos de la isla, y que los jóvenes están liderando el cambio. Las

* Department of Linguistics, SFU. 8888 University Drive. Burnaby BC V5A1S6. 
circunstancias que condujeron a este desarrollo se examinan desde la perspectiva del modelo sociopsicológico propuesto por Britain (1997), y se argumenta que se trata de un caso de reasignación socioestilística (Trudgill 1986). Examinado en el contexto de la tensión sociolingüística que ha existido, durante más de un siglo, entre el grecochipriota y las variedades estándar, la aparición y propagación de una variante nativa es visto como otra muestra de que la situación de la lengua grecochipriota vernácula aumenta dentro de la comunidad.

\section{Palabras clave}

griego, dialectos, chipriota, reasignación, laterales

\section{Introduction}

This study examines the pattern of variation for the variable (liV) in Cypriot Greek. It discusses the results of two separate research projects, one based on sociolinguistic interviews, and one based on elicitation tasks. On the basis of the sociolinguistic interviews, I will argue that although the envelope of variation comprises several variants, the main axis of variation is between the palatal lateral $[\Lambda]$ and the palatal fricative [j], both of which may appear in geminate or short form. The innovative variant is the fricative, which used to be associated mainly with the city of Ammochostos (Famagusta), according to Christodoulou (1967). However, the data from the interviews also show that the variable is rare in free-flowing conversation, and so a second study, based on elicitation tasks was conducted in order to examine the role of linguistic and non-linguistic parameters. These data indicate that the fricative variant is now present in all three major urban centres of the island, and that young men are leading the change. In the discussion, I employ the socio-psychological model proposed by Britain (1997), and argue that this is a case of socio-stylistic reallocation (Trudgill 1986). I also place this change within the more general history of sociolinguistic tension between the stigmatized dialect of Cypriot Greek and the standard, as well as the overall emergence of a Cypriot vernacular, which speakers use in order to negotiate the space between these two extremes (Terkourafi 2005b). From this perspective, the emergence and spread of a native variant can be viewed as another sign that the status of Cypriot Greek vernacular is increasing within the community. 


\section{Variation in the pronunciation of (liV)}

As will be seen below, this variable has barely been noted in the literature, so it is perhaps appropriate to justify it as an object for variationist study. Tagliamonte (2006) uses the term super token to refer to instances in which a single speaker uses two different variants of a variable in the same utterance, because these exemplify the type of variation that is suitable for quantitative analysis. In this corpus, the best example of a super token can be seen in the following excerpt (example 1), where an educated female speaker in her mid-twenties, who is recounting a recent trip to Sweden, switches between a palatal lateral and a palatal fricative in the middle of a noun phrase:

(1) ¡ðame tođimarxio timbaja ipaরa ipoli ine gamlaston we.saw the.city.hall the.old the.old the.city is gamlaston 'We saw city hall the old the old city is called "Gamlaston"?'

In Standard Modern Greek (SMG), the pronunciation is invariably [ $\Lambda$ ], and there are no mentions of variation in other Greek dialects (Newton 1972b, Kontosopoulos 1981). For Cypriot Greek, the earliest mention of this variation comes from Christodoulou (1967), who locates this phenomenon in the cities of Lemesos (Limassol) and Ammochostos (Famagusta). This is a puzzling observation, given that the two cities are about $100 \mathrm{~km}$ apart, the two major urban areas of Lefkosia (Nicosia) and Larnaca are between them, and this report comes before the major movements of Cypriot speakers caused by the war of 1974: Ammochostos is one of the cities that were taken over by Turkish troops, and has remained uninhabited since then. More recently, Arvaniti (1999) also mentions this variation, but according to her it is more characteristic of the region of Larnaca. Menardos (1969), Contossopoulos (1972) and Newton (1972a), however, do not mention this type of variation. Newton states that, [I] is a "voiced alveolar lateral, somewhat palatalized and long before /y/". Thus, even though this variation has been noted in the literature, not much is known about it. 


\subsection{The 2007 dataset}

The first dataset that I will discuss was constructed on the basis of conversations recorded during the spring of 2007 by eight participant-interviewers in Cyprus for the purpose of investigating a syntactic phenomenon. The research assistants were students at the Department of English Studies at the University of Cyprus in Lefkosia, and were trained in terms of fieldwork techniques, ethical standards, etc. The team members were all native speakers of Cypriot from different areas of the southern part of the island, and were instructed to conduct conversations with family members and close friends. The interviewers were able to recruit 52 speakers in three different locations: Lefkosia, which is the capital and is located in the center of the island; Lemesos, the second largest city is located on the coast about $60 \mathrm{~km}$ southwest of the capital; and Larnaca, the third largest city which is also on the coast and $40 \mathrm{~km}$ south of the capital. Four of these interviews contained performances of folk songs and stories, and so were not used in the construction of the database.

The examination of the data revealed an aspect of this variation that poses serious challenges to the usual approach: The variable is rare in everyday conversation. Even though the database comprises over 40 hours of recordings, altogether, only 675 tokens of (liV) were available for extraction. Moreover, these tokens belong to very few types: as can be seen in Table (1), 70\% of the tokens come from just seven different types. Thus, this dataset cannot provide us with a trusted picture of the phenomenon.

\begin{tabular}{lll}
\hline \hline Type & Translation & Tokens \\
/dulia/ & 'work' & 104 \\
/teliono/ & 'finish' & 95 \\
/telia/ & 'completely' & 68 \\
/malia/ & 'hair' & 45 \\
/palio/ & 'old' & 63 \\
/xilia/ & 'thousand' & 65 \\
/yialia/ & 'glasses' & 34 \\
Total & & 474 \\
\hline \hline
\end{tabular}

Table 1. Types and tokens in the 2007 dataset 
However, the dataset does provide some first observations that can help shape the strategy of a more focused investigation. First, there is the issue of the envelope of variation. According to Arvaniti (2010), the variants are a palatal lateral and a long (phonetically geminate) palatal fricative, which is realized as a glide only in weak positions, a finding that is partially confirmed in the present data. Arvaniti also notes that the variant lacks extensive voicing, which is also confirmed in this dataset. A phonetic analysis of the 2007 data reveals a larger set of variants that may occur in conversational situations, including a non-geminate palatal fricative, and a palatal affricate as detailed in Table 2 . Also, both segments (the lateral and the fricative) have geminate and non-geminate variants, whose distribution is not different $\left(x^{2}=0.1405, \mathrm{df}\right.$ $=1, p$-value $=0.7078)$. Thus, the main axis of variation appears to be lateral vs. fricative.

\begin{tabular}{lll}
\hline \hline Variant & Tokens & Coding \\
1. Geminate lateral $[\Lambda:]$ & 142 & lateral \\
2. Non-geminate lateral $[\Lambda]$ & 397 & lateral \\
3. Affricate [gj] & 3 & fricative \\
4. Geminate fricative [j:] & 112 & fricative \\
5. Non-geminate fricative [j] & 293 & fricative \\
6. Glide [j] & 19 & fricative \\
\hline \hline
\end{tabular}

Table 2. The envelope of variation for (liV)

The marginals of the distribution also suggest some areas of interest in terms of its interpretation. As one can see in Table 3, there is an abrupt increase in the use of the fricative variant for speakers born after 1975, which when taken into consideration alongside the spread of the innovative variant to the capital (Lefkosia) indicates that this pattern represents a change in progress. The results for Sex and Education are somewhat contradictory: Women do not prefer the fricative variant, which may be an indication that it lacks prestige, but at the same time we see that this variant is preferred by speakers with an advanced education, which suggests the opposite. 


\begin{tabular}{|c|c|c|c|c|c|c|}
\hline & & \multicolumn{2}{|c|}{ fricative } & \multicolumn{2}{|c|}{ lateral } & \multirow[t]{2}{*}{ Total } \\
\hline & & $\mathrm{N}$ & $\%$ & $\mathrm{~N}$ & $\%$ & \\
\hline \multirow[t]{2}{*}{ Age } & Over 30 & 5 & 3.3 & 148 & 96.7 & 153 \\
\hline & Under 30 & 301 & 57.7 & 221 & 42.3 & 522 \\
\hline \multirow[t]{2}{*}{ Sex } & Male & 51 & 51.5 & 48 & 48.5 & 99 \\
\hline & Female & 255 & 44.3 & 321 & 55.7 & 576 \\
\hline \multirow[t]{2}{*}{ Education } & High school & 75 & 38.9 & 118 & 61.1 & 193 \\
\hline & Post secondary & 231 & 47.9 & 251 & 52.1 & 482 \\
\hline \multirow[t]{3}{*}{ City } & Lefkosia & 97 & 59.1 & 67 & 40.9 & 164 \\
\hline & Lemesos & 99 & 39.9 & 149 & 60.1 & 248 \\
\hline & Larnaca & 110 & 41.8 & 153 & 58.2 & 263 \\
\hline Total & & 306 & 45.3 & 369 & 54.7 & 675 \\
\hline
\end{tabular}

Table 3. Distribution of fricative vs. lateral palatal usage by Age, Sex, Education and City

Given the different percentages of use for men and women and according to a speaker's level of education, one might ask about the general awareness of this variation. Within the Labovian paradigm (Labov 1972, 2001), there are three recognized types of sociolinguistic variables which are associated with speakers' awareness: indicators (no awareness), markers (subconscious awareness) and stereotypes (conscious awareness). Themistocleous (2008) in her dissertation on orthographic

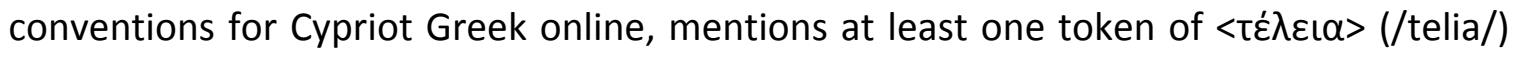
spelled <teja>. The use of $\langle j>$, suggests conscious awareness of the fricative pronunciation. However, the evidence in the 2007 dataset is inconclusive. On the one hand, there is evidence of awareness as in example (2), where the male speaker first uses the fricative variant in the word [ðuja], but, in his second turn, switches to the lateral ([ðu^a]), most likely recognizing the use of the lateral by the participantinterviewer. On the other hand, there are many instances of conversations between fricative and lateral users where the variants are juxtaposed without incident. Furthermore, in two cases, interviewers instruct their mothers to speak Cypriot, but the correction does not seem to apply to the lateral vs. fricative distinction. One such case can be seen in example (3), where the mother of a participant-interviewer uses the 
phrase [ayreha metavya] "asparagus with eggs" (a Cypriot shibboleth), with a lateral in the word for asparagus, but a fricative-fricative combination (SMG pronunciation) in the word for "eggs." The daughter asks her to "speak in Cypriot," and the mother obliges by producing a fricative-stop combination in "eggs," but does not change the pronunciation of [ayreha]. Thus, the variable does not appear to be a stereotype, but it is not clear whether it is an indicator or a marker.

(2)

\begin{tabular}{clllll} 
Chr & stiðuja & mu & fonazun & me & $\mathrm{k}^{\mathrm{h}}$ ristin \\
& at.work & I.POSS & call.PRES.3PL & I.DO & Christine \\
Int & stiðuka & indalos & se & lalusi & \\
& at.work & how & you.DO & call.3PL.PRES & \\
\multirow{2}{*}{ Chr } & stiðuka & lalun & me & $\mathrm{k}^{\mathrm{h}}$ ristin & \\
& at.work & call.PRES.3PL & I.DO & Christine &
\end{tabular}

“Christos: ' 'At my work they call me Christine (in jest)'

Interviewer: 'What do they call you at work?'

Christos: 'At work they call me Christine.'”

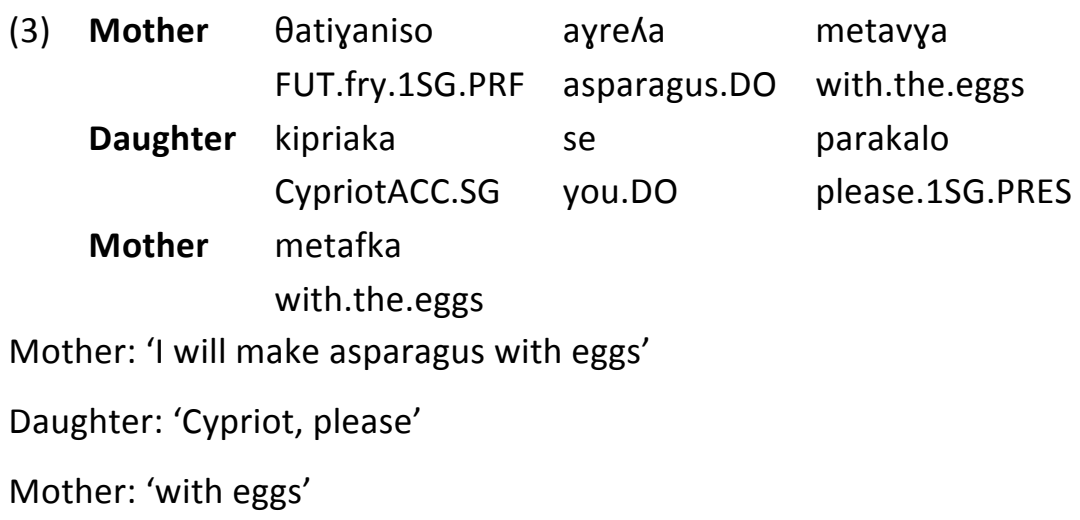

\subsection{The 2011 dataset}

As the above discussion has shown, the analysis of the data from the 2007 study leaves several key questions about the variation unanswered. So, in a 2011 study, I trained four native speakers of Cypriot and graduate students in the Linguistics Program of the Department of English, who interviewed 27 speakers in their families and circle of

\footnotetext{
${ }^{1}$ This and other speaker names are pseudonyms.
} 
friends. Since the variable had proven to be rare, the focus of these interviews was on elicitation tasks. They began with a brief general discussion about Cyprus (food, life, work opportunities), and then proceeded to the reading of a rural-themed passage, which had been specially constructed to contain instances of the (liv) variable, and finally the task of naming items in a slideshow. These were 48 items that were selected because they contain the variable (liv), and could be represented graphically, so as not to influence speakers' pronunciation by showing them SMG spelling.

There were 12 male and 15 female participants. Since the first study demonstrated that the variable was only used by younger speakers, the second study focused on speakers below the age of 35 . The median age of the participants was 23 , the minimum being 16, and the maximum 34. They lived in the cities of Lefkosia, Lemeso, and Larnaca, the three major cities of Cyprus. As expected, the variable rarely occurred in the conversational sections of the interviews. The elicitation tasks, on the other hand, produced a total of 2406 tokes, 105 of which had to be excluded for technical reasons. The remaining 2301 tokens were analyzed using GoldVarb Lion (Sankoff, Tagliamonte \& Smith 2012). A number of linguistic factor groups were examined: position in the word, nature of the following and preceding vowel, the provenance of the word (Greek or Cypriot), and stress of the syllable. The non-linguistic factors examined were gender (operationalized as sex), education, region of residence (operationalized as city), and attention to speech (operationalized as linguistic task). Due to the rarity of the variable it was not possible to construct a perfectly balanced sample for all the linguistic factors, and thus most of those cells were empty or underpopulated. 


\begin{tabular}{lllll}
\hline \hline Input $=.752$ & \multicolumn{2}{l}{ Log likelihood $=-1245.1$} & \multicolumn{2}{l}{ Total N = 2301 } \\
& & & & \\
Group & Factor & Weight & $\%$ & $\mathrm{~N}$ \\
\hline Following V & /e/ & 0.59 & 80 & 317 \\
& /a/ & 0.5 & 73 & 1586 \\
& /o/ & 0.39 & 65 & 398 \\
Range & & 20 & & \\
& & & & \\
Sex & male & 0.68 & 87 & 963 \\
& female & 0.36 & 63 & 1338 \\
Range & & 32 & & \\
& & & & \\
Task & text & 0.53 & 75 & 1097 \\
& images & 0.47 & 71 & 1204 \\
Range & & 6 & & \\
& & & & \\
City & Lefkosia & {$[0.52]$} & 77 & 570 \\
& Lemesos & {$[0.52]$} & 71 & 668 \\
& Larnaca & {$[0.47]$} & 72 & 1063 \\
\hline \hline
\end{tabular}

Table 4. Multivariate analysis results for the use of the fricative variant in 2011 data.

The optimal model which can be seen in Table 4, includes only one linguistic factor, the nature of the following vowel with front and back high vowels $(/ \mathrm{i} /, / \mathrm{u} /)$ combined with their mid counterparts (/e/ and /o/), because of the small number of tokens for the former. All factors are significant, except for city of residence. In terms of the following vowel, the front vowel favours the fricative variant and the back vowels disfavour it, while [a] is at 0.5 weight. The sex of the speaker is the most important nonlinguistic factor, with men favouring the innovative variant while women do not. The difference between the two tasks is also significant with fricative variant being favoured in the reading task. In fact, it is probably the case that this difference is underrepresented. The text composed for the reading task was unavoidably written with SMG spelling conventions, since Cypriot Greek does not have its own writing system. The use

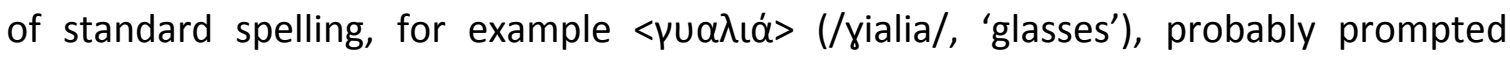
speakers to use the standard pronunciation more than they may have otherwise.

Taken together, the results of the analysis of the two datasets lead to the following conclusions: The fact that region is not a significant factor suggests that the 
variation between the lateral and fricative variants is a supra-local feature of the Cypriot Greek vernacular. The rapid spread of the fricative among urban speakers below the age of 30 suggests that this is a case of change from above, in the sense that it has its source in a regional variety (Labov 2001). Furthermore, men are leading the change, and the innovative variant appears to be a marker of less formal speech. In the next section I explore the implications that these findings have for the status of Cypriot Greek.

\section{Discussion}

Before attempting an analysis of the change described above, it is necessary to provide a brief description of the sociolinguistic tension experienced by the Greekspeaking community of Cyprus, both in terms of its historical development and its current situation, because these are crucial parameters for understanding the environment within which this change is taking place.

In Cyprus one finds the interesting phenomenon that its Greek-speaking community, despite living in a British colony for most of its modern history (1878-1960), has been mainly influenced - politically, culturally and linguistically - by developments in mainland Greece. For example, the attempt of the new British government in 1878 to establish an English-based curriculum in Cypriot schools, an approach that has been successful in other colonial settings ${ }^{2}$ was met with fierce resistance, mainly by the Greek-speaking population with the support of the Greek Orthodox Church (Karyolemou 2001). As a result, the local variety of Cypriot Greek did not develop simply in contradistinction to an administrative language imposed by the colonial power (English). It also existed in opposition to standard Greek, which, due to the irredentist ambitions of the newly independent Greek state, was imposed in domains such as church language, education, and literature through a policy of providing books, curricula and teachers for Greek-speaking communities (cf. Karagiorges 1986; Koliopoulos 20002002). In effect, Cypriot Greek became a third-class language in its own country.

These tensions continued even after Cyprus gained its independence in 1960. It is

\footnotetext{
${ }^{2}$ Kamwangamalu (2010) discusses the staying power of colonial languages in Africa despite efforts of decolonization.
} 
telling that the first fracture in the tenuous relationship between the Turkish and Greek Cypriot communities was signalled by the 1964 decision of the latter to officially follow mainland Greece educational (i.e., linguistic) policies. Three years later, in 1967, a rightwing military junta took over in Greece and began to undermine the left-leaning government of Cyprus led by Archbishop Makarios. The destabilization effort culminated in 1974, when Makarios was overthrown and nearly assassinated. The coup established a pro-Greek puppet government, which gave Turkey the legal basis to intervene militarily, ostensibly to restore the constitution, although it appears that such an invasion had been long in the planning by Turkey, the US, and Britain. There were two assaults, one in July and one in August, which resulted in the division of the island into two territories: the northern part for Turkish Cypriots and the southern part for Greek Cypriots. Thousands of Greek Cypriots had to become refugees within their own country and eventually all Turkish Cypriots relocated from the south to the northern part of the island (Hitchens 1984; Mallinson 2005).

It was inevitable that such a catastrophe would imbue the language question with even more layers of meaning, but it also had practical consequences. The influx of refugees into the southern urban centres of Lefkosia, Lemesos and Larnaca would mean a drastic reorganization of the dialect map of Cypriot Greek and intensified dialect contact. Several thousand Greek Cypriots found refuge in Greece, which after seven years of military dictatorship was just establishing a European style democracy for the first time in its modern history. The expanding Greek University system reserved seats for Cypriot Greek students and Greek teachers were offered positions in the Cypriot education system, chiefly in order to implement the teaching of the new vernacular SMG in Cypriot schools. However, since the Cypriot dialects had been isolated from the rest of the Greek world for a millennium, and under more intense contact with other languages (Arabic, French, Turkish, and English; cf. Browning 1983; Horrocks 2010), SMG was not a koiné that Cypriot Greek speakers could relate to. It was just a more simplified version of a high language imposed on them, and this time, it was not just the Greek of the Church, or classical education, it was also the Greek of the military junta who had brought devastation to the island. Thus, while some continued to think of Cyprus as a part of Greece and of standard Greek as an integral part of their identity, others began 
to seek an alternative, more independent Cyprus with its own Cypriot vernacular.

According to Terkourafi (2005a), the events of 1974 served as a catalyst for the emergence of a Cypriot koiné, which she labels gCG (generalized Cypriot Greek.) She makes the case that this koiné is ultimately based on the urban varieties that began to emerge after the island passed to the control of the Lusignan Franks, and continued developing through the Ottoman Empire. The process was accelerated first during the Great Depression in the 1930s, and then even more so after WWII, both due to the industrialization of the island and, more importantly, because of the development of better transportation networks. In Cyprus, the main method of urbanization was not relocation to the major urban centres, but rather commuting, which actually led to a more widespread loss of distinction between the rural and urban varieties, as commuters brought city norms back to their home villages (Terkourafi 2005a).

The sociolinguistic relationship between the koiné and SMG remains a controversial issue. Some (e.g., Sciriha 1996; Moschonas 1996; Panayotou 1996, Rowe \& Grohmann 2013) describe it as a diglossic situation, with SMG as the high variety, while others (Arvaniti 2002; Tsiplakou et al. 2006) treat it as a continuum of vernaculars. Goutsos \& Karyolemou (2004) suggest that it is a complex relationship where perception is different from practice, i.e., the situation is perceived as diglossic but usage is along a continuum which ranges from the basilectal "village" Cypriot (horkatika) to the acrolect that urban and highly educated speakers use (horaitika), and which does not keep strict boundaries between Cypriot and SMG.

To understand how such a dichotomy between perception and practice may have emerged, it is useful to examine the language education experience of a Greek Cypriot child during his or her formative years. ${ }^{3}$ Up until the age of three, she is spoken to in gCG, and can use it without censure. At the age of four, she will be enrolled in kindergarten, where corrective instruction towards SMG will begin. At six, she will enter elementary school where instruction will take place in SMG, and she will also start learning English. At eight, English instruction will begin in earnest, and at 12 she will be asked to start learning French. Finally, at 16, if French is not agreeable to her, she will begin learning yet another language (most select Italian, Spanish or German). At

\footnotetext{
${ }^{3}$ I thank one of the graduate students at UCY, Maria Tenizi, for providing me with this information.
} 
university, instruction will continue in SMG, for the most part, and in English in certain courses. According to Tsiplakou et al. (2006: 273), adult speakers "switch relatively smoothly from one choice to another" and that these choices may include SMG forms which are considered part of the acrolect. This description makes it clear that gCG is relegated to the status of an undesirable code at a very early age, and never gains any overt prestige. Corrective instruction towards SMG begins at kindergarten at the precise time that Vernacular Reorganization (Labov 2001) begins, in other words just as children are becoming attuned to sociolinguistic variation (four years old). However, both at this stage and throughout their education, Cypriot children are being corrected about the use of dialectal forms by teachers who use many dialectal forms themselves, thus leading to a disconnect between perception and usage that Goutsos \& Karyolemou (2004) refer to.

Whatever the cause of this disconnect may be, it has led to the kind of sociolinguistic tension that is typical of such situations (cf. Milroy \& Milroy 1985; Fasold 1990, Wolfram \& Schilling-Estes 1998). Papapavlou (1998) in a matched-guise test found that Cypriot speakers judge the local variety as sounding uneducated and unpolished, while they also judge SMG speakers as insincere, unfriendly and manipulating. In several studies on language use by Cypriot media, Pavlou (2004) discovered that, although most mass media communication is conducted in SMG, gCG is preferred for advertising of Cypriot products, especially those that have to compete with foreign ones.

From a structural perspective, according to Terkourafi (2005b), gCG shows all the key characteristics of a koiné as it is based on the regional lect of Mesaoria (the area around the capital city Lefkosia) and has developed through simplification and levelling processes that are the result of contact between the various regional varieties, as well as influence from SMG. Based on various studies that have taken place in the past century (Menardos 1969; Contossopoulos 1972; Newton 1972a), Terkourafi identifies almost three dozen features (from all components of the grammar) that characterize this koiné in contradistinction with either SMG or more localized varieties of the language (i.e., "village" Cypriot). Typical examples of such innovative features include:

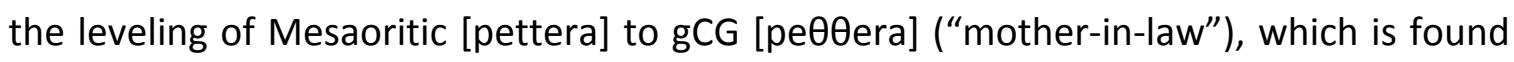
in the other varieties of Cypriot Greek, through the influence of SMG [peӨera]; the 
simplification of genitive and accusative plurals for nominals of all genders; and the blending of Mesaoritic [omorca] and SMG [omorfça] to produce gCG [omorfca] ("beauty").

The spread of the regional variant [j] within this koiné, then, presents an important development, since this appears to be the first instance in which a local variant is elevated to supra-local status. I will attempt to explain this change as a case of reallocation, a process that Trudgill (1986) has demonstrated can also be a result of dialect contact and koinéization, in addition to simplification, levelling, and blending. In reallocation, variants from regional varieties may survive into the koiné by acquiring a different embedding. Britain \& Trudgill (2005), discuss several examples of the phenomenon, showing that sometimes the embedding is socio-stylistic in nature, while other times it is structural. For example, the koiné of Norwich is the product of contact between the regional varieties of West, South, and North and East Norfolk. In terms of the pronunciation of words in the ROOM lexical set, there were three different regional variants, (tense, lax, and fronted, respectively), which still persist, but have taken on a socio-stylistic role: The tense variant has high status, the lax middle status, and the fronted variant has low status. In a different example, during the formation of the Anglo-Australian community two variants of the BATH set came into contact: Northern English /æ/ and Southern /a:/. Even though the latter was a prestigious variant, it was not adopted wholesale. Both variants still exist, with /æ/ appearing only before nasal codas (plans, dance, etc.), giving us an example of structural reallocation.

The pattern of variation in Greek Cypriot (liV) appears to be the result of sociostylistic reallocation, as the regional variant [j] has been adopted as a marker by male speakers in gCG. This observation strengthens the conclusion by Terkourafi (2005b) that gCG is indeed a koiné involving the regional dialects of Cyprus, since in this case we see the spreading of a regional feature across the island, whereas the other changes that have occurred involve the assimilation of SMG features in one way or another. However, before we adopt this position, it is important to demonstrate that the socio-historical conditions that are thought to lead to koinéization also existed during the emergence of this variable.

Britain (1997) proposes that dialect contact situations lead to koinéization because 
they place speakers in situations in which their ontological security is threatened. He adopts the term from the social model of Giddens (1984), in which routinization - "the habitual, taken for granted character of the vast bulk of activities of day-to-day social life" - plays a very important role. Routinization helps people establish ontological security, defined by Gregory (1989) as an individual's mode of confidence that results from his or her ability to participate in daily life in a mostly predictable way.

Britain also makes the claim that situations of dialect contact, even when they are produced by voluntary movement of people results in a loss of routinization, and of ontological security. In order to mitigate the anxiety brought about from such disorientation, people will "open themselves to others, forming new ties of friendship and intimacy" (p. 40). Finally, he suggests that this process of re-grounding requires individuals that are more likely to converge, and here the role of children is important as they are "complete accommodators [...] and in situations where no one variety is dominant, they rationalize the linguistic resources of the community around them." Kerswill (2001: 673) supports this view as well: "for a koiné to form, the speakers must waive their previous allegiances and social divisions to show mutual solidarity. Where they do not, koinéization is slowed, or may not result at all."

If we take stock of the events that surround the emergence of (liV) in Cypriot Greek, it quickly becomes clear that they did produce the social and political environment that Britain describes. The war of 1974 resulted in loss of life and property, the displacement of populations, and the scattering of many northern Cypriot-Greek communities across the southern half of the island. This, in turn, resulted in demographic and infrastructure pressures on the host communities, bringing about both a disruption of routinization and a major threat to the ontological security of all Cypriots, one that would not dissipate easily.

In fact, one could argue that it was not until the 1990s that the situation in Cyprus stabilized. Up until the mid 1980s, it was hoped that the "Cypriot problem" could be resolved and that refugees would be able to return to their hometowns, thus prolonging the period of "routinization disruption" by placing everyone in a state of limbo. In 1983, the Turkish Cypriot side declared itself an independent state making reunification of the island unlikely. This impressed upon refugees the necessity of integrating with Greek- 
Cypriot communities in the southern part of the island. The government began a program of parceling out state-owned lands around the three major cities by a lottery system, so there was no systematic relocation of the refugee population as integral communities.

At the same time, the Greek Cypriot community was achieving financial and political success as an independent state: whereas the per capita GDP in 1980 was 4,384 USD, by 1990 it had risen to 9,971 USD (UNSD 2012); 1989 saw the establishment of the University of Cyprus which admitted its first students in 1992; the Cypriot state began developing closer ties to the European Union leading to full membership in the Eurozone (2005); and there has been a significant rise of the merchant marine and financial services sector. This eventually led to a reversal of brain-drain, with many expatriates (or their children) returning to Cyprus and a significant increase of mainland Greeks being employed in Cyprus (TSE 1992, 2011). Thus, as the situation in Cyprus was stabilizing, and the population (both refugees and hosts) began to accept the new status quo, it appears very likely that children born after 1974, and who would have been entering adolescence in the late 1980s and early 1990s, would act as the accommodators in Britain's model, and accelerate the koinéization process that had started after WWII.

It is not surprising that a variant such as [j] would be reallocated, especially if Christodoulou (1967) is correct about it being a characteristic of the Ammochostos region. This city, built near the cite of the ancient city state of Salamis, is today a ghost city, having remained uninhabited since 1974 , and so maintains iconic status in terms of the loss of life, property and security that followed the invasion. It is not clear, however, why such a role would be assigned to a feature that is so rare in usage as (liV). One can only speculate, but it may be that as a rare feature, the use of the fricative variant, does not colour one's speech as too basilectal while at the same time giving it the appropriate tenor of alignment with local values. In a study of the stigmatized / / and /n/ palatalization in Greece (Pappas 2006), participants remarked that any attempt of a speaker to mitigate the extent of palatalization did in fact improve their overall image. Wolfram (1974) has also argued that the price tag of adoption of a marked feature may sometimes be too costly. On the other hand, the rare occurrence of the variable may 
also explain why a basilectal feature has such a high input probability $(0.75)$ despite the overall prescription against "village" speech.

In terms of the sociolinguistic situation in Cyprus, the biggest implication of this socio-stylistic reallocation is that it provides evidence that gCG has emerged as the de facto vernacular standard. Despite the feelings of linguistic inferiority by Cypriot speakers reported in earlier studies, more recent research (Arvaniti 2002; Tsiplakou 2004) indicates that Cypriot speakers are becoming more self-confident, and are more positive towards their native variety. As Terkourafi (2005b: 335) notes:

Such a wealth of new productive mechanisms and novel constructions is not what one expects of a retreating variety, and attests to the overall vitality of the Cypriot Greek dialectal continuum, though of course different elements may be falling out of use, as new ones emerge.

This, in turn, means that we can no longer talk of Greek Cypriots as a diglossic community, if it were ever appropriate, because as Kerswill (2001) notes koinés do not have a target language. The koinéization process described in the work of Terkourafi and the emergence of (liV) as a socio-stylistic marker lead us to the conclusion that we do not have a binary opposition between Cypriot and Standard Greek, but rather a continuum that ranges from basilectal varieties (horkatika) all the way to acrolectal varieties (horaitika), and that the latter are standard enough. In fact they are so good, that for certain speakers, or in certain occasions, they do not pass as adequately Cypriot, and must be "enhanced" (cf. Tsiplakou \& Ioannidou 2012). The following excerpt from Tsiplakou (2004) is a case in point. Here, the speaker expresses her overt disapproval of the use of the basilectal [eyoni] ('I') while at the same time she herself uses mostly gCG features (underlined) in phonology, morphology and syntax.

ne, en xorkatika pu lalun kori mu. ercete sto komotirion epses mja korua, đekapende xrono, đen iksero akrivos, ce lali mu eyoni. akuis stavrul:a mu? eyoni. kori mu lalo tis, esi ise lefkosiatis:a kori mu. esi ise xoraitis:a. inda tropos en tutos na lalis eyoni? ufu! lali mu t $\underline{\text { e fefci }}$ 
Yes, they speak like peasants dear. A girl comes into the salon yesterday, fifteenyears old, I don't know exactly, and she says to me 'eyoni'. Did you get it, Stavroula dear? 'eyoni'. My dear, I told her, you are from Lefkosia, my dear. You are from the city. What is this way of speaking, to say 'eoni'? "Whatever!" she said and left.

In this respect Cypriot Greek is not that different from other regional varieties of the language. The standard, as all standards, is an idealized abstraction that no one actually speaks and serves as an umbrella under which the varieties can be united. The reasons why this protection is not extended to Cypriot Greek as it is to Cretan (which is similar to Cypriot) or even Arvanitika (the now extinct ethnolect of 17th century Albanian settlers and their descendants) are historical and political, not linguistic. But note, that the price that these other regional varieties have had to pay in order to join in under the umbrella is the shrinking role of their most basilectal forms, and consequently their continued (although partial) homogenization. So perhaps by being on the outside, Cypriot Greek will be able to carve its own trajectory of change and maintain its status as the most vigorous of Greek regional varieties.

\section{References}

ARVANItI, A. (1999) "Cypriot Greek", Journal of the International Phonetic Association, 29, 2, 173 178.

ARVANITI, A. (2002) "Dimorfia, diglossia, ke i emfanisi tis Kipriakis Neoelinikis Kinis" [Bimorphism, diglossia and the emergence of Cypriot Modern Greek Koiné], in C. Clairis (ed.), Recherches en linguistique grecque: Actes du 5 e colloque international de linguistique grecque (Sorbonne, 13-15 September 2001), Paris: L'Harmattan, 75-78.

ARVANITI, A. (2010) "A (brief) overview of the phonetics and phonology of Cypriot Greek", in A. Voskos, D. Goutsos \& A. Mozer (eds.), Proceedings of the conference on 'The Greek language in Cyprus from antiquity to today', University of Athens, 23-24 May 2008, Athens: University of Athens, 107-124.

BRITAIN, D. (1997) “Dialect contact and phonological reallocation: 'Canadian Raising' in the English Fens", Language in Society, 26, 1, 15-46.

BRITAIN, D. \& P. TRUDGILL (2005) “New dialect formation and contact-induced reallocation: Three 
case studies from the English Fens", International Journal of English Studies, 5, 1, 183-209. BRownING, R. (1983) Medieval and Modern Greek, Cambridge, UK: Cambridge University Press. CHRISTOdoulou, M. N. (1967) "Sintomos simiosis peri tis siniziseos en ti Kipriaki dialekto" [A brief note on coalescence in the Cypriot dialect], Kypriakai Spoudai, 31, 93-97.

CONTOSSOPOULOS, N. (1972) "Aspects du phonetisme chypriote", in Epetiris tu Kentru Epistimonikon Erevnon, vol. 6, Nicosia: Cyprus Research Centre, 93-107.

FASOLD, R. W. (1990) The Sociolinguistics of Language, Oxford, UK; Cambridge, USA: Blackwell.

GIDDENS, A. (1984) The Constitution of Society: Outline of the Theory of Structuration, Cambridge: Polity Press.

Goutsos, D. \& M. KARYolemou (2004) "Introduction", International Journal of the Sociology of Language, 168, 1-17.

GREGORY, D. (1989) "Presences and absences: Time-space relations and structuration theory", in D. Held \& J. Thompson (eds.), Social theory of modern societies: Anthony Giddens and his critics, Cambridge: Cambridge University Press, 185-214.

HITCHENS, C. (1984) Cyprus, London: Quartet Books.

HORROCKS, G. C. (2010) Greek: A History of the Language and its Speakers, Oxford, Malden, Massachusetts: Wiley-Blackwell.

KAmWANGamalu, N. (2010) "Vernacularization, globalization, and language economics in nonEnglish-speaking countries in Africa", Language Problems and Language Planning, 34, 1, 123.

KARAgIORgeS, A. (1986) Education Development in Cyprus, Nicosia: [s.n.].

Karyolemou, M. (2001) "From linguistic liberalism to legal regulation: The Greek language in Cyprus", Language Problems and Language Planning, 25, 1, 25-52.

KeRSWILL, P. (2001) "Koinéization and accommodation", in J. K. Chambers, P. Trudgill \& N. Schilling-Estes (eds.), The Handbook of Language Variation and Change, Malden, Massachussetts: Blackwell, 669-702.

Koliopoulos, I. (2000-2002) Istoria tis Ellados apo to 1800 [History of Greece since 1800], Athens: Ekdoseis Banias.

Kontosopoulos, N. (1981) Dialekti kai Idiomata tis Neas Elinikis [Dialects and Local Varieties of Modern Greek], Athens: [s.n.].

LABOV, W. (1972) Sociolinguistic Patterns, Philadelphia: University of Pennsylvania Press.

LABOV, W. (2001) Principles of Linguistic Change. Volume II: Social Factors, Oxford: Blackwell. MaLLINSON, W. (2005) Cyprus: A Modern History, London: I.B. Tauris. 
MenaRdos, S. (1969) Glosike Melete [Linguistic Studies], Nicosia: Cyprus Research Centre.

MILROY, J. \& L. MILROY (1985) Authority in language: approaches to language standardisation and prescription, London, Boston: Routledge and K. Paul.

Moschonas, S. (1996) "Diglossia stin Kypro [Diglossia in Cyprus]", in A.-Ph. Christidis (ed.), 'Strong' and 'Weak' Languages in the European Union: Aspects of linguistic Hegemonism, Thessaloniki: Center for the Greek Language, 120-128.

NeWTON, B. (1972a) Cypriot Greek: Its Phonology and Inflections, Janua Linguarum, Series Practica, 121, Mouton de Gruyter.

NEWTON, B. (1972b) The Generative Interpretation of Dialect: A Study of Modern Greek Phonology, Cambridge: Cambridge University Press.

Panayotou, A. (1996) "Le chypriote contemporain: essai de description", Travaux de la Maison de l'Orient Mediterrane en (Chypre hier et aujourd'hui, entre Orient et Occident), 25, 121125.

Papapavlou, A. (1998) "Attitudes toward the Greek Cypriot Dialect: Sociocultural implications", International Journal of the Sociolinguistics of Language, 184, 1, 15-28.

PAPPAS, P. A. (2006) "Stereotypes and /n/ variation in Patras, Greece: results from a pilot study", in F. Hinskens (ed.), Language Variation - European Perspectives: Selected papers from the Third International Conference on Language Variation in Europe (ICLaVE 3), Amsterdam, June 2005, Amsterdam: John Benjamins, 153-167.

Pavlou, P. (2004) "Greek dialect use in the mass media in Cyprus", International Journal of the Sociology of Language, 168, 101-118.

Rowe, C. \& K. K. GROHMANN (2013) “Discrete bilectalism: towards co-overt prestige and diglossic shift in Cyprus", International Journal of the Sociology of Language, 224, 119-142.

SAnkoff, D., S. A. TAgliamonte \& E. SMith (2012) GoldVarb Lion: A Multivariate Analysis Application [http://individual.utoronto.ca/tagliamonte/goldvarb.htm.]

SCIRIHA, L. (1996) A Question of Identity: Language Use in Cyprus, Nicosia: Intercollege Press.

TAgliamonte, S. A. (2006) Analysing Sociolinguistic Variation, Cambridge and New York: Cambridge University Press.

TeRKoURAFI, M. (2005a) "Identity and semantic change: Aspects of T/V usage in Cyprus", Journal of Historical Pragmatics, 6, 2, 283-306.

TeRKoURAFI, M. (2005b) “Understanding the present through the past: Processes of koinéisation in Cyprus", Diachronica, 22, 2, 309-372.

THEMISTOCLEOUS, C. (2008) The use of Cypriot Greek in Synchronous Computer-mediated Communication, Ph. D. thesis, University of Manchester. 
Dialectologia 15 (2015), 159-179.

ISSN: 2013-2247

TRUDGILL, P. (1986) Dialects in Contact, Oxford: Basil Blackwell.

TSE (1992) Apographi Plithismou 1992 [Census 1992], Nicosia: Ipourgio Ikonomikon: Tmima Statistikis kai Erevnon.

TSE (2011) Apographi Plithismou 2011 [Census 2011], Nicosia: Ipourgio Ikonomikon: Tmima Statistikis kai Erevnon.

TSIPLAKOU, S. (2004) "Stasis apenanti sti glossa ke glosiki alagi: mia amfidromi sxesi? [Stances towards language and language change: a mutual relationship?]", in Proceedings of the 6th International Conference of Greek Linguistics, Rethymnon, 20 September 2003, [accessed July 2014, http://www.philology.uoc.gr/conferences/6thICGL/ebook/g/ tsiplakou.pdf.]

TSIPLAKOU, S. \& E. IOANNIDOU (2012) "Stylizing stylization: The case of Aigia Fuxia", Multilingua, 31, 277-299.

Tsiplakou, S., A. Papapavlou, P. Pavlou and M. Katsoyannou (2006) “Leveling, koinéization, and their implications for bidialectalism", in F. Hinskens (ed.), Language Variation - European Perspectives: Selected papers from the Third International Conference on Language Variation in Europe (ICLaVE 3), Amsterdam, June 2005, Amsterdam, Philadelphia: John Benjamins Publishing Company, 265-276.

UNSD (2012) National Accounts Estimates of Main Aggregates, United Nations.

Wolfram, W. (1974) "The relationship of White Southern speech to Vernacular Black English", Language, 3, 498-527.

WolfRAM, W. \& N. SCHILLING-ESTES (1998) American English: Dialects and Variation, Malden, MA: Blackwell. 